\title{
THE PORNOGRAPHY WARS Exploring Two Distinct Feminist Identities
}

MEREDITH HUDSON

CURRENT POLITICAL DEBATES OVER THE LEGALIZATION OF GAY MARRIAGE AND THE PROTECTION OF A WOMAN'S REPRODUCTIVE RIGHTS RARELY QUESTIONS THE CRITICAL REASONS WHY OUR SOCIETY UPHOLDS BOTH PATRIARCHAL AND HOMOPHOBIC VALUES. THIS ARTICLE EXPLORES ONE SUCH WAY IN WHICH A PATRIARCHY IS SUSTAINED BY THE USE OF IMAGES, SPECIFICALLY PORNOGRAPHIC IMAGES. THOUGH MANY FEMINISTS WOULD WANT TO PURSUE A BAN ON PORNOGRAPHY, SUCH A BAN WOULD MERELY REINFORCE THE IDEA THAT CERTAIN SEXUAL DESIRES BETWEEN TWO CONSENTING ADULTS ARE IMMORAL AND DECRADING. CONDEMNATION OF IMAGES SUCH AS THESE HAS PERPETUATED THE RIGHT FOR OUR CULTURE TO UPHOLD HOMOPHOBIA FOR MANY DECADES, THEREFORE, WE, AS A SOCIETY, MUST BE WARY OF SUCH A POLICY. 


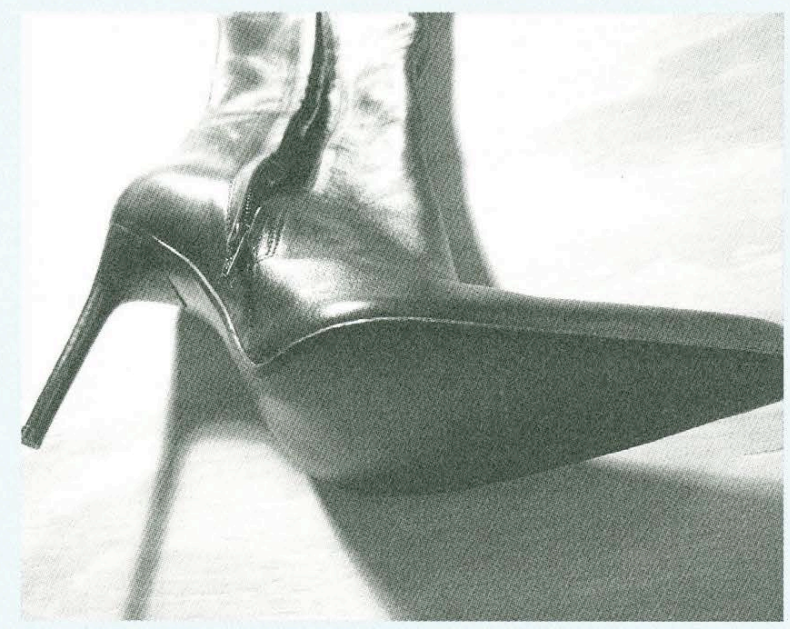

INTRODUCTION

Though the tumultuous decade of the I960s appeared to shake the very foundations of the American nation, many beneficial consequences also arose. Various minority groups became mobilized; African-Americans fought for their right to vote, women fought for their right to equal opportunity, and gays fought for the right to practice their lifestyle free from the fear of police entrapment. Concurrent with the political upheaval of this time, a social revolution was occurring as well. The counter-culture movement was promoting causes such as "free-love," and the invention of the birth control pill made this possible. The sexual revolution focused on liberating society from inhibitions about sexuality and encouraged sexual exploration. As a result of this cultural phenomenon, pornography became more widespread. For some feminists, this proliferation of sexual imagery was not liberating; rather it problematized the role of women in our society and presented them as objects merely to serve and submit to male sexual pressure. This particular school of feminism saw all sexuality as a form of male violence; every act of sexuality is inherently a situation of domination and control of the female by the male. During the I970s and early I980s, radical feminists formed a coalition with conservative Christian groups such as the Moral Majority to ban pornography. These political efforts ultimately failed to make pornography illegal, but the pornography debates reveal significant tension and conflict about the identity of a feminist, as well as the role of women's sexuality. It sparked a conflict among those in the feminist movement, as well as from other sexual minorities. Some groups claimed banning pornography not only intrudes upon First Amendment rights, but also, by legislating sexuality and morality, risked marginalizing those who did find sexual pleasure and liberation in pornography or other devious sexual acts.

\section{FEMINIST ARGUMENTS AGAINST}

\section{PORNOGRAPHY}

Though feminists against pornography enacted several local-level strategies to regulate pornography, none were as controversial as the Dworkin-MacKinnon ordinance, since it defined pornography as a direct violation of women's rights. ${ }^{i i}$ Andrea Dworkin and Catherine MacKinnon proposed anti-pornography legislation to the city of Minneapolis in I980 that legally defined pornography as

\section{The graphic, sexually explicit subordination of women whether in pictures or in words that also includes one or more of the following: women are presented dehumanized as sexual objects,... or women are presented as sexual objects who enjoy pain or humiliation; or women who ex- perience pleasure in being raped...or women's body parts are exhibited, such that women are reduced to those parts; or women are presented in scenarios of egradation...shown as filthy or inferior, bleeding, bruised or hurt in a context that makes these conditions sexual. ${ }^{\text {iii }}$}

The law proposed civil, not criminal, action for those affected by pornography; it provided a legal framework in which those affected by pornography would have the legal right to sue makers, sellers, distributors and exhibitors of pornography. The law also provided for a court injunction to remove pornography from the public realm, so that publishers and booksellers would be under constant scrutiny and surveillance. ${ }^{\text {iv }}$ Feminists sought to evaluate the detrimental effects of pornography on three levels: 
production, the product itself, and the consumers of the product. Pornography is a $\$ 7$ billion a year industry; there are more X-rated bookstores than McDonalds in the United States. ${ }^{y}$ Eighty-four percent of men and 69 percent of women have seen pornography, though few reported, or were willing to report, that they watched pornography frequently. Ninety percent of pornography is directed at heterosexual males; most consumers are white, middle-class males. Among the adult population there is no consensus as to the effects of pornography; forty-nine percent believes it is a cause for men to commit rape, 47 percent claim it improves sex within marriage, and 56 percent believe it leads to a break down of morals. ${ }^{\text {vi }}$ Ten percent of women reported that someone tried to inflict undesired sex acts on them that came directly from pornography, while among married women 24 percent reported such acts. ${ }^{\text {vii Given }}$ these statistics, even an objective observer would admit that pornography has a notable effect on American culture. the domination of women. Pornography is the "material means of sexualizing inequality." viii The subordination of women occurs in four parts: hierarchy, objectification, submission, and violence. Violence is a particularly problematic aspect of women's marginalization as men perceive that women like violence, they find pleasure in rape, and love in battery. Images within pornography solidify and reinforce this perception.ix MacKinnon asserts that the "male gaze" has transformed women into merely objects of pleasure and gratification; women are not naturally subordinate individuals but the oppressive institution of patriarchy has transformed women into this position. ${ }^{X}$ For MacKinnon and Dworkin all sexuality is violence, the penis is a tool of invasion and domination. Consensual sex between adults can never exist.xi They argue that, despite progress in women's rights, inequalities will exist as long as the sexual subordination of women does. Pornography is not the only reason why these inequalities exist, but it is the

\section{"Pornography is a $\$ 7$ billion a year industry; there are more X-rated bookstores than McDonalds in the United States."}

In order to understand the theoretical arguments articulated by Mackinnon and Dworkin in both the definition of pornography and the regulations suggested by the Minneapolis Ordinance, one must understand the framework of feminism to which both women adhered. Some authors define Mackinnon and Dworkin as radical femnists, and others refer to them as cultural feminists. Regardless of the terminology, these women and their followers began to make the claim that "the personal is the political;" women's oppression in sex flows into other aspects of her life: health care, reproductive rights, employment opportunities, and politics. Sexual subordination is the medium through which women are oppressed. During sex the woman is the passive, weak object whose sole purpose is to pleasure the male in any way he desires. Inequality itself becomes sexualized as sexual pleasure is based off of medium that presents women as submissive and "asking for violence." For these reasons, radical feminists thought pornography must be eliminated from society for progressive change to occur.

The production of pornography itself is problematic as those involved in the industry have come forth with stories of rape and coercion. Women who have starred in pornographies often report rape and assault by men who presume their sexual availability. Linda Marchiano, the star of the pornographic film Deep Throat, was abducted, beaten, and forced to star in the pornography. Children are manipulated and black-mailed to star in pornography, many times by their own parents. Many pornography actresses are driven into the industry as a way to escape poverty. xii For these reasons, radical feminists pushed for 
pornography to be viewed not as an obscenity but as a civil rights violation. Expression made when one party is forced to speak in a manner that violates their rights and dignity in not protected under the First Amendment. xiii The radical feminists argue that even "feminist pornography" that is directed by and marketed towards women is problematic because it merely recycles the detrimental mode of pornographic representation. The specifics of pornography are irrelevant; the representation of women in a sexual manner is in itself violent. xiv

\section{REACTIONS AGAINS'T}

\section{ANTI-PORNOGRAPHY FEMINISTS}

The critics of the anti-pornography feminists believed the ordinances brought forth by MacKinnon and Dworkin were too widespread. Many feminists, specifically the lesbian-feminists and the S/M feminists found their sexual practices under scrutiny and condemnation by the very people that were supposed to be fighting for the rights of women. Though many women suffer the bad effects of pornography, there are those women who find pornography pleasurable, educating, and even liberating and were not willing to curtail their own sexuality for a group of women who did not address their interests in the first place. ${ }^{x v}$ A misconception about those who defended pornography is that they did recognize the exploitation and the abuse that existed within the industry; however, they knew that some people do chose to make pornography. They defended pornography to a degree: as long as the meanings expressed within the images did not directly imply the subordination of or violence towards women, it should be allowed. Many defenders of pornography did see violence as a problem, but believed its causes were mainly structural and social conditions. ${ }^{\text {xyi }}$ As a result of McCarthystyle attacks anyone even remotely related to the pornography industry was condemned as a sexual pervert. Sexual deviants, specifically those in the leather community, felt their livelihood was being threatened, and began to confront the Women Against Pornography (WAP) for fear that the feminist movement had morphed into a campaign not for women's rights, but for moral purity. The leather commu- nity was particularly vocal in addressing the images presented in pornography and the cultural significance attached to those meanings. For them, scenes of sadomasochistic torture were not violence for the sake of violence, but rather signified a source of pleasure and arousal. Meanings assigned by the dominant culture to $\mathrm{S} / \mathrm{M}$ sex were not the same as the meanings those assigned within the community. They felt that dominant culture was not entitled to regulate their sexual passions and desires. xvii

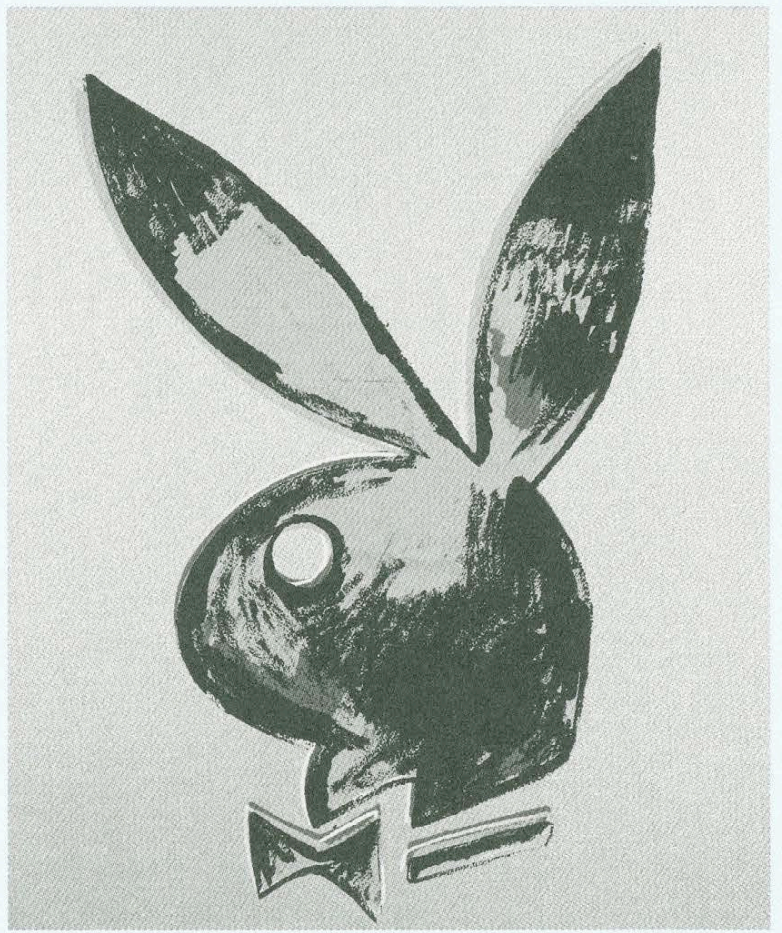

As sex radical Pat Califia (a leather lesbian who is now a transsexual bisexual male) stated, "The line between word and deed is a thin one. A desire that cannot be named or described is a desire that cannot be valued, acted upon or used as the basis for identity."xviii Califia and others thought that the initiatives taken by the anti-pornography feminists sought to regulate acceptable and unacceptable sexual identities, a process that is dehumanizing and leaves individuals feeling isolated. 
Lesbians specifically found the radical feminists condemnation of female sexuality to be problematic. For them, the female body is sexual and desirable based on their own terms, not on the terms of men. If feminists were fighting for the inclusion of women into society as autonomous and free individuals, then women should have the capacity and the right to chose when to consent to sex and went to refrain. Stating that no sex, even between adults, can be consensual undermines the capacity of women to make the best decisions for their own lives. For many women, erotic experiences enhance their lives, and by denying the right to view pornography, the anti-pornography feminists were actually prohibiting women from being sexually aggressive, lustful, and nonconventional. This would reinforce the stereotype that women are sexually passive. ${ }^{x i x}$ The critics of MacKinnon and Dworkin debunked the idea that all sex is male violence by claiming:

whether sexual intercourse is a political act of men subjugating women depends upon its interpersonal context which determines, say, a woman's possibilities for initiating, negotiating, and refusing the act, as well as her ability to define the place of vaginal intercourse in the entire sexual and social exchange.xx

Some critics of the anti-pornography feminists even claim that pornography enables women to experience the same sexual freedom as men, which is necessary before one can hope to have social equality. Autonomous individuals must have the right to explore sexual pleasures and to pursue the lifestyle of their own choice. None of the defenders of pornography advocated things such as bestiality, pedophilia, or rape, but did staunchly defend the sexual choices of two consenting adults. xxi

Many critics of MacKinnon and Dworkin argued from the perspective of the First Amendment. Legal theorists argued that the scope of the Ordinance brought forth by MacKinnon and Dworkin was much too large; it allows for the potential censorship of novels, art, plays, movies and other cultural media that make any reference to sexuality involving the female body. This scope contradicts the essence of the amendment, which states that the impact of speech cannot be grounds for the government control of speech. Enacting such policies encourages a totalitarian control on the population by the government. ${ }^{x x i i}$

\section{CONCLUSION}

The debates over pornography exposed serious controversy and conflict within the feminist movement. Both sides recognized the negative and exploitative characteristics of pornography, such as reinforcing images of male domination within society. Many felt a ban on pornography, however, would do more harm than good for several reasons. By ascribing which types of sexual behaviors are acceptable (and which are not), the government would be unjustly regulating the identity of its population. Those who defended pornography criticized the radical feminists for not recognizing the way the female body can be sexual in the terms of other women and not merely as the object of men's pleasure and desire. The attempt to ban all pornography may have resulted in an attempt to establish strict norms about sexuality. For many people, sexuality is an important, personal, and exciting aspect of their lives that they would never want to be regulated by the government. While just what constitutes appropriate sexuality remains a topic of debate, many modern men and women have found ways to form sexual communities in which they can freely explore pleasure and eroticism in any way they please.

\section{ENDNOTES}

i. Mackinnon, 66

ii. Dines, I9

iii. Dworkin, 29

iv. Duggan, Hunter, and Vance, I3I

v. Douglas, I4

vi. Goldstone, Io

vii. Mackinnon, 69

viii. Dworkin, 30

ix. Dworkin, 30

x. MacKinnon, 67

xi. Dworkin, 30

xii. MacKinnon, 62-63

xiii. Carse, 2

xiv. Dines, 20 
xv. Califia, 174

xvi. Seidman, 109

xvii. Califia, I2, 13, I8

xviii. Califia, I9

xix. Seidman, I09-III

xx. Seidman, II2

xxi. Seidman, II4

xxii. Emerson, 8I

\section{REFERENCES}

Califia, Pat. Public Sex: The Culture of Radical Sex. San Francisco: Cleis Press: 2000.

Carse, Alisa L. "Pornography: An uncivil liberty?" Hypatia IO.I (1995): p. I55.

Dines, Gail. "The Visual Landscape and the Politics of Pornography Production." Iris 33 (I995): p r6.

Douglas, Carol Anne. "Pornography: Liberation or Oppresion?" off our backs I3.5 (I983): p. I4.

Duggan, Lisa, Nan Hunter, and Carole S. Vance. "False Promises: Feminist Antipornography Legislation in the U.S." Women Against Censorship. Ed.Varda Burstyn. Toronto: Douglas \& McIntyre, 1985. 130-I5I.

Dworkin, Andrea. "Against the Male Flood: Censorship, Pornography, and Equality." Harvard Women's Law Journal 8 (I985).

Emerson, Thomas I. "Pornography and the First Amendment: A Reply to Professor MacKinnon." Yale Policy and Law Review $130(1984)$.

Goldstone, Bobbie: "The politics of pornography: the pornography of politics." off our backs I.I4 (1970): p. 10.

MacKinnon, Catherine A. "Francis Biddle's Sister:

Pornography, Civil Rights, and Speech." Feminism Unmodified. Cambridge: Harvard University Press. 1987

Seidman, Steven. Embattled Eros: Sexual Politics and Ethics in Contemporary America. New York: Routledge, I992. 